\title{
Budidaya Ikan Lele dengan Sistem Bioflok untuk Kawasan Permukiman
}

\author{
Candra Dwiratna Wulandari ${ }^{1}$, Sudiro ${ }^{1}$, Titik Poerwati ${ }^{2}$ \\ ${ }^{1}$ Departemen Teknik Lingkungan, ${ }^{2}$ Departemen Perencanaan Wilayah dan Kota, \\ Institut Teknologi Nasional Malang \\ Jl. Bendungan Sigura-gura No.2, Malang, 65152, Indonesia
}

\section{ARTICLE INFO: \\ Received: 2020-07-23 \\ Revised: $2020-08-16$ \\ Accepted: $2020-10-28$}

Keywords:

aerasi, bioflocs, catfish

\section{ABSTRACT}

Households themselves should fulfill their nutritional needs by using the home page. Limited land in residential areas is one of the constraints that limit this. One of the Rukun Tengga (RT) in Tlogomas Village, namely RT 05 RW 03 is a new RT, which does not yet have complete infrastructure, to catch up every year it is planned and budgeted to develop these facilities and infrastructure. One of them is in the field of food security, RT 05 tries to meet the needs of vegetables, fruit and fish in the surrounding environment, so catfish farming is developed using conventional methods. The problem faced by the manager is that catfish cultivation is not optimal so that the mortality of catfish seeds reaches 50 percent, and another obstacle is the presence of an unpleasant odor. To solve this problem, the biofloc method was carried out to improve the catfish culture system. From the efforts to improve catfish culture by means of biofloc, there are benefits, among others, the percentage of seed mortality has decreased to 20 percent, the cost of feed is more efficient, does not cause odor and the development of catfish is maximized. The yields are in accordance with market demand, namely, with a weight of $1 \mathrm{~kg}$ as many as 8 fish at the age of 2.5 months.

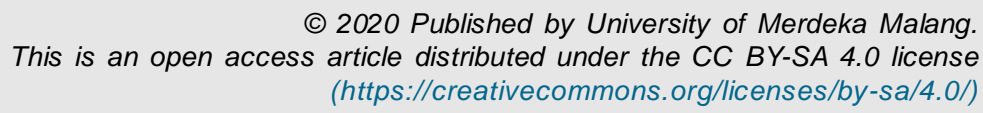

How to cite: Wulandari, C. D., Sudiro, \& Poerwati, T. (2020 Budidaya Ikan Lele dengan Sistem Bioflok untuk Kawasan Permukiman. Abdimas: Jurnal Pengabdian Masyarakat Universitas Merdeka Malang, 5(3), 286-293. https://doi.org/10.26905/abdimas.v5i3.4044

\section{PENDAHULUAN}

Secara nasional, pada akhir tahun 2018 rata-rata penduduk Indonesia masih mengkonsumsi ikan sebesar $47 \mathrm{~kg}$ per kapita per tahun, masih di bawah rata-rata konsumsi Malaysia dan Singapura yang masing-masing 56,2 kg dan 48,9 kg. Kementerian Kelautan dan Perikanan Republik Indonesia (KKPRI) menargetkan konsumsi ikan masyarakat Indonesia akan meningkat hingga mencapai 50,8 kg per kapita per tahun hingga akhir 2018 (Pebrianto, 2018). 


\section{Budidaya Ikan Lele dengan Sistem Bioflok untuk Kawasan Permukiman \\ Candra Dwiratna Wulandari, Sudiro, Titik Poerwati}

Untuk meningkatkan konsumsi ikan di masyarakat perlu adanya sosialisasi pentingnya konsumsi ikan bagi keluarga. Penelitian yang dilakukan oleh Prameswari (2018) menunjukkan bahwa untuk meningkatkan kegemaran makan ikan perlu adanya promosi gemar makan ikan pada anak usia sekolah. Hasil penelitian menunjukkan 98,1 persen subjek menunjukkan kegemaran makan ikan. Anak usia sekolah lebih gemar makan olahan ikan sebagai selingan (snack) dengan bahan dasar ikan.

Untuk tetap dapat membudidayakan ikan untuk keluarga maka perlu adanya inovasi budidaya perikanan untuk daerah perkotaan yang memiliki lahan sempit. Budidaya ikan lele sistem bioflok dikembangkan di DKI Jakarta untuk memenuhi pasokan pangan yang cukup dan terjamin. Teknologi bioflok dipilih karena hemat lahan, hemat air sehingga sangat cocok untuk dikembangkan pada daerah perkotaan dan permukiman yang padat (Nugroho, 2020). Selain itu sistem bioflok mampu mendongkrak produktifitas karena pada lahan yang sempit dapat diproduski ikan lele yang lebih banyak, biaya produksi berkurang, dan waktu yang relatif singkat jika dibandingkan dengan budidaya secara konvensional (Gaffar et al., 2020; Sumardani et al., 2018).

Pada saat ini budidaya perikanan yang dilakukan dalam skala kecil menggunakan sistem konvensional, pada sistem ini mempunyai beberapa kekurangan antara lain, membutuhkan biaya yang besar dan waktu yang cukup lama, sedangkan hasil tidak melimpah. Budidaya perikanan secara konvensioanl tidak dapat memenuhi target pasar yang meningkat sebesar 80 persen tiap tahunnya (Faridah et al., 2019).

Budidaya ikan dengan sistem bioflok mulai banyak dikembangkan. Sistem ini memiliki kelebihan antara lain: meningkatkan kelangsungan hidup (survival rate/SR) hingga lebih dari 90 persen dan tanpa pergantian air. Air bekas budidaya tidak berbau sehingga tidak mengganggu lingkungan sekitar dapat disinergikan dengan budidaya tanaman misalnya sayur-sayuran dan buah-buahan (Pramono et al., 2018). Dengan sistem bioflok mampu mengolah limbah untuk meminimalkan limbah sekaligus mendaur ulang limbah menjadi pakan. Hal ini merupakan jalan keluar dalam menciptakan budidaya ikan yang ramah lingkungan, berkelanjutan, efisien dalam penggunaan air maupun pakan (Rizal, 2018).

Provinsi Jawa Timur memiliki luas wilayah total seluas $47.799,75 \mathrm{~km}^{2}$, yang terbagi menjadi 29 Kabupaten dan 9 Kota. Kabupaten Banyuwangi merupakan Kabupaten terluas dengan luas wilayah 5.782,4 $\mathrm{km}^{2}$, sedangkan kota yang terluas yaitu kota Surabaya luas $350,54 \mathrm{~km}^{2}$, kota Surabaya juga memiliki jumlah penduduk terbanyak yaitu 2.896 juta jiwa. Sedangkan untuk wilayah yang memiliki luas paling kecil yaitu Kota Mojokerto dengan luas wilayah 16,47 km², dengan jumlah penduduk paling sedikit, yaitu 129 ribu jiwa (Provinsi Jawa Timur dalam angka, 2020). Kota Malang merupakan kota besar kedua setelah Kota Surabaya dengan luas wilayah 110,06 km² yang terbagi menjadi 5 kecamatan, dengan jumlah Rukun Warga (RW) sejumlah 550 dan Rukun Tetangga (RT) sejumlah 4.226. Pada tahun 2019 jumlah penduduk kota Malang sebanyak 927.285 jiwa dengan pertumbuhan penduduk rata-rata 1,23 persen pertahun.

Kecamatan Lowokwaru mempunyai luas wilayah sebesar 22,60 $\mathrm{Km}^{2}$, yang terdiri dari 12 kelurahan, 544 Rukun Warga (RW) dan 4.111 Rukun Tetangga (RT). Salah satu kelurahan di Kecamatan Lowokwaru adalah Kelurahan Tlogomas, yang merupakan pintu masuk sebelah barat Kota Malang, sehingga mempunyai potensi untuk berkembang dengan pesat. Selain itu di Kelurahan Tlogomas memiliki fasilitas pendidikan yang lengkap mulai dari pendidikan dasar sehingga pendidikan tinggi/ perguruan tinggi, hal ini menyebabkan kelurahan Tlogomas menjadi lingkungan yang padat penduduk, termasuk di Rukun Tetangga (RT) 05 RW 03 Kelurahan Tlogomas. Untuk meningkatkan kesejahteraan warga RT 05 RW 03, pengurus bidang pembangunan memiliki program kerja penghijauan dan upaya pemenuhan kebutuhan pangan dari pekarangan sendiri. Salah satu upaya untuk menjalankan program tersebut, dengan pembagian bibit Tabulapot (Tanaman Buah dalam Pot) sebanyak 50 bibit yang dibagikan kepada setiap rumah untuk ditanam dan di rawat, jika rumah tersebut tidak memiliki lahan, Tabulapot ditanam di tanah kosong disekitar 
ABDIMAS: Jurnal Pengabdian Masyarakat Universitas Merdeka Malang Volume 5, No 3, November 2020: 286-293

RT 05 dan menjadi tanggung jawab warga untuk merawat. Selain itu juga dikembangkan Hydroponik untuk memenuhi kebutuhan sayur. Saat ini warga RT 05 mencoba membudidayakan ikan dengan metode konvensional, ikan yang dikembangkan adalah ikan lele. Dari budidaya yang dilakukan saat ini terkendala dengan kurangnya lahan, serta kurang bagusnya sirkulasi udara, sehingga budi daya ikan lele tidak maksimal. Bibit lele yang ditebar pada kolam sebanyak 500 ekor, karena adanya keterbatasan $50 \%$ dari bibit mati. Dan pada saat pemanenan ukuran ikan lele tidak memuaskan yaitu jumlah lele sebanyak 12-15 ekor per kilogramnya. Untuk menyempurnakan budidaya ikan lele tersebut, maka dilakukan perubahan sistem budidaya dengan sistem bioflok.

Program pengabdian masyarakat ini adalah memberikan penyuluhan dan pendampingan untuk meningkatkan keterlibatan warga RT 05 RW 03 Kelurahan Tlogomas untuk melakukan budidaya ikan lele dengan menggunakan sistem bioflok yang ramah lingkungan dan dapat meningkatkan kualitas hidup dan hasil panen ikan lele tersebut.

\section{METODE}

Adanya potensi dan permasalahan yang dialami oleh warga RT 05 RW 03 Kelurahan Tlogomas, maka dipandang perlu untuk mengadakan kegiatan yang menunjang program ini, dengan memberikan penyuluhan dan pendampingan budidaya ikan lele dengan metode yang lebih ramah lingkungan. Kegiatan ini mengikuti langkah-langkah kerja dengan mengikuti flowchart pada Gambar 1.

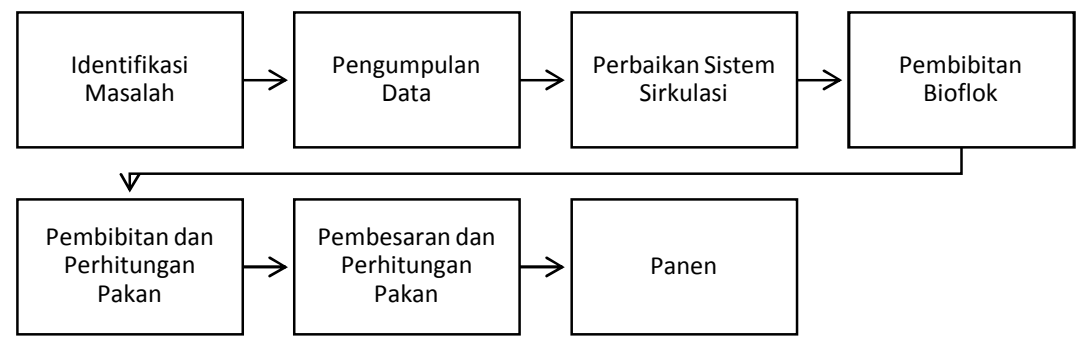

Gambar 1. Skema Kegiatan

Tahap pertama kegiatan ini adalah mengidentifikasi masalah dan pengumpulan data, untuk mendapatkan data kesulitan pengelola, dilakukan wawancara dengan pengelola budidaya ikan lele (Gambar 2).
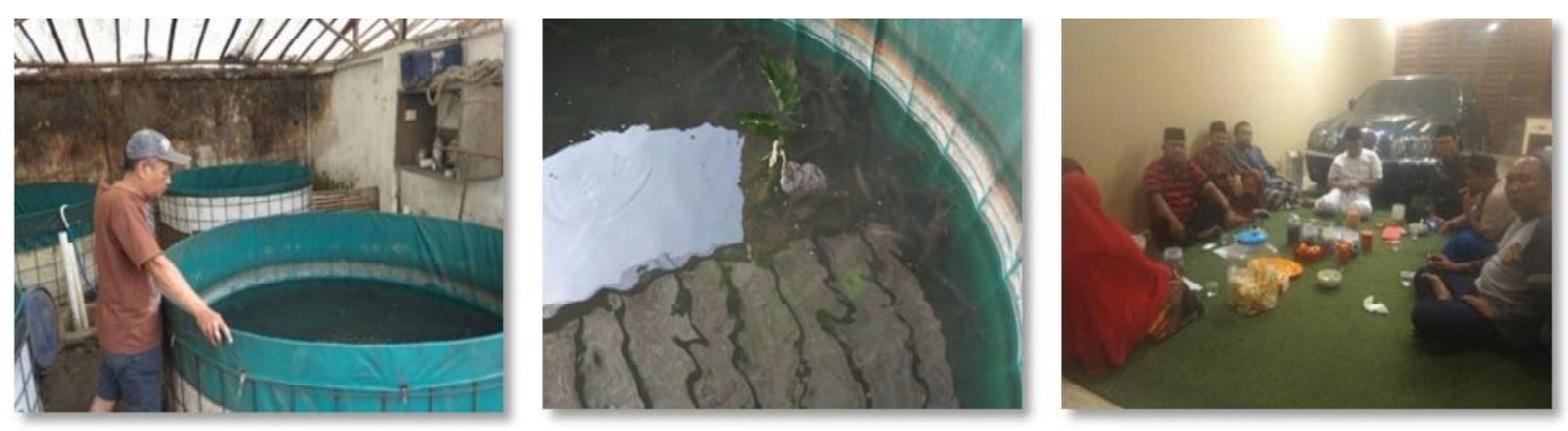

Gambar 2. Wawancara dengan pengelola

Gambar 3. Kondisi kolom lele saat ini

Gambar 4. Sosialisasi dengan warga 


\section{Budidaya Ikan Lele dengan Sistem Bioflok untuk Kawasan Permukiman \\ Candra Dwiratna Wulandari, Sudiro, Titik Poerwati}

Hasil wawancara dengan pengelola didapatkan beberapa permasalahan yaitu kematian bibit lele sebesar 50 persen, pakan yang diberikan tidak efisien dibanding dengan hasil panen, kelebihan pemberian pakan akan menyebabkan pakan terbuang serta penyebabkan bau pada kolam, dan dapat berdampak tidak baik pada ikan. Budidaya lele dengan metode konvensional, kurang memperhatikan kualitas dan kuantitas pakan ikan. Pakan yang diberikan terkadang kurang sesuai dengan kebutuhan gizi yang diperlukan oleh ikan lele. Di sisi lain, dengan sistem budidaya konvensional memungkinkan tingkat kematian ikan yang cukup tinggi. Tidak hanya itu, sisa pakan tambahan buatan juga dapat menurunkan kualitas media budidaya. Terutama meningkatnya kandungan amoniak (Setiawan et al., 2016). Sebelum dilakukan perbaikan sistem budidaya, maka dilakukan sosialisasi kepada masyarakat terutama pengelelo budidaya lele. Sosialisasi dilakukan pada saat pertemuan rutin yang dilakukan oleh pengurus RT 05 RW 03 Kelurahan Tlogomas.

Tahap kedua, Untuk memperbaiki sistem budidaya tersebut dilakukan perbaikan sistem sirkulasi aerasi, dengan pemasangan aerator. Metode budidaya yang digunakan adalah sistem bioflok. Pada sistem bioflok ini diperlukan aerasi selama 24 jam, penambahan aerator yang berfungsi untuk menambah konsentrasi oksigen pada kolam. Sistem bioflok membutuhkan konsentrasi oksigen terlarut sebesar 5 $\mathrm{mg} / \mathrm{l}$, hal ini disebabkan oleh adanya bakteri heterotrof penyusun bioflok yang membutuhkan oksigen

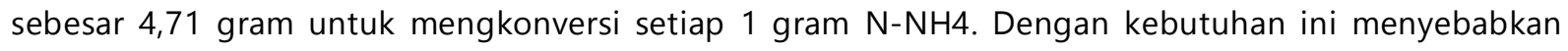
konsentrasi oksigen terlarut pada kolam ikan relatif rendah hinga mencapai 1,5-2 gram/liter. Jika konsentrasi oksigen terlarut dalam kolam ikan rendah berdampak pada nafsu makan ikan turun, sehingga berdampak pada hasil panen. Untuk menambah konsentrasi oksigen terlarut pada kolam ikan dapat dilakukan dengan ditambahkan agitasi permukaan air (kincir) dan difusi udara melalui diffuser aerator (batu aerasi). Metode kerja diffuser dan aerasi yaitu dengan memaksa udara melalui media berpori yang menghasilkan gelembung dengan jumlah banyak. Tujuan aerasi adalah membuang gas yang berbahaya seperti N2 dan CO2 dan untuk meningkatkan konsentrasi oksigen terlarut dalam air (Sumitro et al., 2020).

Langkah ketiga pembibitan bioflok yang berfungsi untuk membantu pengolah limbah hasil budidaya. Selain berfungsi sebagai pengolah limbah juga berfungsi sebagai pakan ikan. Sistem bioflok, merupakan metode batch dimana air media kultur hanya sekali dimasukkan dan digunakan sampai panen. Penambahan air untuk menggantian penguapan dan pengontrolan kepadatan bioflok (Ombong \& Salindeho, 2016). Persiapan media kultur bioflok dengan cara inokulasi bakteri prebiotik, yang digunakan adalah EM4 (Effective Microorganisms-4) yang mengandung bakteri Lactobacillus casei dan Saccharomyces cerevisiae. Sebanyak $250 \mathrm{ml}$, dan ditambahkan larutan gula pasir sebagai pengganti molase sebanyak $10 \mathrm{gram} / \mathrm{m}^{3}$ yang dilarutkan dalam air dan di aduk secara merata di media kultur, sdangkan sumber Nitrogen dapat menggunakan pupuk urea sebanyak $1 \mathrm{~g} / \mathrm{m} 3$ air (Ma'ruf, 2016). Kolam di diamkan selama kurang lebih 4 (empat) hari sampai bioflok tumbuh dengan baik. Pertumbuhan bioflok ditandai dengan warna air pada kolam berwaran hijau. Warna air pada suatu sistim bioflok dapat berubah tergantung tahapan perkembangan awal bioflok, komposisi utama flok dan tingkat kepadatan flok. Air medium bioflok dapat berwarna hijau jika flok didominasi oleh algae, sementara jika flok mulai didominasi oleh bakteri maka warna akan berubah menjadi kecoklatan. Kepadatan flok yang tinggi serta suspended-solids yang padat menyebabkan medium air menjadi coklat gelap, ciri lain adalah terbentunya gelembung pada permukaan kolam (Ombong \& Salindeho, 2016).

Menurut Salamah \& Zulpikar (2020), bioflok dapat berfungsi sebagai pakan tambahan dan penyedia sumber protein, meningkatkan aktivitas protease dalam sistem pencernaan makanan, yang pada akhirnya 
ABDIMAS: Jurnal Pengabdian Masyarakat Universitas Merdeka Malang

Volume 5, No 3, November 2020: 286-293

menghasilkan peningkatan pemanfaatan pakan ikan, Selain dapat memperbaiki kualitas air, teknologi bioflok diharapkan dapat meningkatkan efisiensi pakan yang berpengaruh terhadap penambahan bobot pada ikan (Adharani et al., 2016).

Tahap keempat pembibitan dan perhitungan pakan. Setalah kolam sudah siap, dilakukan penebaran bibit lele dengan ukuran kurang lebih $10 \mathrm{~cm}$, bibit lele yang di tebar sebanyak 500 ekor. Dipilih sebenyak 500 ekor karena sebagai pemula budidaya ikan lele. Pemilihan bibit lele sangat berpengaruh pada pertumbuhan dan perkembangan lele. Dari 500 ekor bibit yang ditebar kurang lebih 10 persen dari bibit mengalami kematian. Hal ini disebabkan antara lain, proses adaptasi dari kolam bibit ke kolam pembesaran yang menyebabkan bibit tidak dapat beradaptasi dengan keadaan baru lingkungannya. Adanya kompetisi diantara bibit ikan serta ikan terlalu banyak makan. Hal ini sesuai dengan penelitian Ma'ruf (2016) dimana menyatakan penggunaan benih lele berkualitas baik berukuran antara 9 sampai $12 \mathrm{~cm}$ dengan kepadatan antara 300 sampai 3000 ekor per $\mathrm{m}^{3}$ (bagi pemula disarankan hanya 300-500 ekor per $\mathrm{m}^{3}$ ). Penggunaan benih lele ukuran antara $9 \mathrm{~cm}$ sampai $12 \mathrm{~cm}$ memperkecil risiko kegagalan karena benih lele lebih stabil dan pertumbuhan ikan relatif sudah seragam.

Perhitungan pemberian pakan ikan lele, yaitu antara 3-6 persen dari berat lele. Untuk mengetahui berat lele, ditimbang satu kilogram sebagai sampel, kemudian dihitung berapa jumlahnya. Jumlah bibit yang ditebar 500 ekor, kemudian diambil sampel $1 \mathrm{~kg}$ berisi 25 ekor berarti 500/25 = $20 \mathrm{~kg}$. Kemudian 20 $\mathrm{kg} \times 3 \%=0,6 \mathrm{~kg}, 200 \mathrm{~kg} \times 6 \%=1,2 \mathrm{~kg}$. Jadi pemberian pakan antara 0,6-1,2 kg/ hari. Pemberian pakan akan dilakukan 5 (lima) sehari pada saat awal, dan berkurang 3 (tiga) kali sehari, selama masa perkembangan.

Tahap kelima yaitu pembesaran Untuk mengetahui perkembangan ikan lele yang dibudidayakan maka dilakukan pengukuran panjang ikan serta penimbangan berat ikan setiap minggu. Penimbangan dilakukan setiap seminggu sekali untuk menghindari stress pada ikan, yang berakibat pada ikan yang mati.

\section{HASIL DAN PEMBAHASAN}

Perbaikan sistem sirkulasi udara pada kolam ikan lele, dan dilakukan perhitungan kebutuhan pakan ikan lele. Perhitungan pakan disesuaikan dengan umur lele serta berat badan ikan. Pemberian pakan dilakukan secara bertahap, pada tahap awal pembibitan pemberian pakan dilakukan sebanyak 4 kali sehari, dengan interval waktu 2 -4 jam sekali. Pemberian pakan berangsur berkurang dari waktu ke waktu (Syam, 2019).

Budidaya ikan membutuhkan pakan sebagai penunjang pertumbuhan, pakan yang diberikan tidak semua termakan oleh ikan karena sebagian pakan hanya $25 \%$ yang dikonversi sebagai hasil produksi dan sisanya terbuang sebagai limbah (62\% berupa bahan terlarut dan $13 \%$ berupa partikel terendap (Suryaningrum, 2014). Setelah masa pembibitan pemberian pakan sebayak 2 (dua) kali sehari, yaitu pagi dan sore hari, dengan sistem bioflok adanya tambahan pakan alami dapat menghemat biaya pakan. Sesuai dengan pernyataan Zulfahm \& Syahimi (2018), bahwa terjadinya pertumbuhan berat dan panjang yang tinggi tersebut diduga karena adanya suplai pakan tambahan dari flok yang ada dalam wadah pemeliharaan. Adanya tambahan pakan alami pada media, berasal dari asimilasi nitrogen dan carbon anorganik menjadi protein mikroba bakteri heterotrof yang telah ditambahkan ke dalam media pemeliharaan. Tabel 1 menunjukkan pemberian pakan yang disesuaikan dengan berat ikan per minggu. 
Tabel 1. Komposisi berat ikan lele dengan berat pakan ikan

\begin{tabular}{ccc}
\hline Minggu & Berat lele (gr) & Berat pakan (gr) \\
\hline 1 & $2,5-5$ & $6-5$ \\
2 & $5-20$ & $5-4,5$ \\
3 & $20-50$ & $4,5-4$ \\
4 & $50-80$ & $4-3$ \\
5 & $80-100$ & $3-2$ \\
6 & $>100$ & 2 \\
\hline
\end{tabular}

Tabel 2 menunjukkan perkembangan bibit lele selama 3 (tiga) bulan, setelah dilakukan perbaikan sistem dengan metode bioflok dan perhitungan efisiensi pakan. Ikan lele dipanen setelah 3 (tiga) bulan mengikuti selera pasar, permintaan pasar, dan berat yang disukai $1 \mathrm{~kg}$ berisi 8 ekor.

Besar kecilnya nilai efisiensi pakan yang dihasilkan tidak hanya berdasarkan pemberian pakan yang diberikan, melainkan dipengaruhi oleh beberapa faktor seperti kepadatan berat setiap individu, suhu, air, dan cara pemberian pakan (frekuensi pemberian pakan, kualitas dan penempatan) (Dediyanto, 2019).

Tabel 2. Berat ikan lele

\begin{tabular}{cccc}
\hline Minggu ke & Berat (Gram) & Minggu ke & Berat (Gram) \\
\hline 1 & 4 & 7 & 120 \\
2 & 15 & 8 & 130 \\
3 & 30 & 9 & 155 \\
4 & 75 & 10 & 170 \\
5 & 100 & 11 & 185 \\
6 & 110 & 12 & 200 \\
\hline
\end{tabular}

Hasil panen yang dihasilkan ikan lele sebanyak $20 \mathrm{~kg}$, dengan berat masing-masing sebesar 200 gram. Dengan berat ikan lele tersebut sesuai dengan permintaan pasar. Selanjutnya budidaya ikan lele dilakukan oleh masyarakat sendiri.

Pertumbuhan ikan dipengaruhi oleh beberapa faktor yaitu, pakan yang diberikan, kualitas air, sirkulasi udara dan suhu air budidaya. Faktor ini berpengaruh terhadap pertumbuhan ikan karena dapat menunjang percepatan pertumbuhan dan mempercepat waktu pemanenan (Dediyanto et al., 2019).

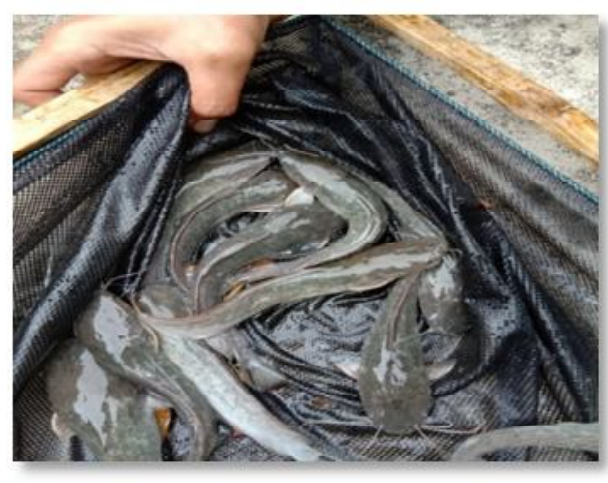

Gambar 6. Panen ikan lele

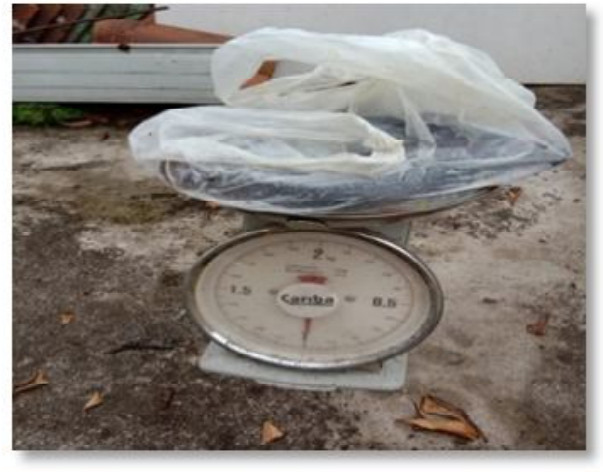

Gambar 7. Penimbangan ikan lele 
ABDIMAS: Jurnal Pengabdian Masyarakat Universitas Merdeka Malang

Volume 5, No 3, November 2020: 286-293

\section{SIMPULAN DAN SARAN}

\section{Simpulan}

Transfer teknologi dengan cara pemdampingan budidaya ikan lele dengan sistem bioflok yang telah dilakukan dapat menjawab kendala pengelola budidaya ikan lele di RT 05 RW 03 Keluruhan Tlogomas. Dengan perubahan sistem budidaya kematian bibit lele dapat ditekan, pemberian pakan lebih efisien, hasil panen yang memuaskan, hemat air, dan tidak menimbulkan bau.

\section{Saran}

Salah satu kelemahan dari sistem bioflok adalah harus menjaga kepadatan bioflok yang ada di dalam kolam agar kepadatan sesuai dengan standar, untuk itu perlu adanya pengujian secara berkali untuk kualitas air kolam sehingga kepadatan biolflok dapat terjaga dengan konstan.

\section{DAFTAR PUSTAKA}

Adharani, N., Soewardi, K., Syakti, A. D., \& Hariyadi, S. (2017). Manajemen kualitas air dengan teknologi bioflok: Studi kasus pemeliharan ikan lele (Clarias Sp.). Jurnal Ilmu Pertanian Indonesia, 21(1), 35-40. https://doi.org/10.18343/jipi.21.1.35

Dediyanto, K., Sulistiono, Utami, A. U., \& Adharani, N. (2019). Akselerasi performa ikan lele dengan sistem bioflok menggunakan probiotik fish megaflok. Jurnal Lemuru, 1(2), 34-43.

Faridah, F., Diana, S., \& Yuniati, Y. (2019). Budidaya ikan lele dengan metode bioflok pada peternak ikan lele konvesional. CARADDE: Jurnal Pengabdian Kepada Masyarakat, 1(2), 224-227. https://doi.org/10.31960/caradde.v1i2.74

Gaffar, A. A., Rasyid, A., \& Suryaningsih, Y. (2020). Budidaya Ikan Lele Sangkuriang dengan sistem bioflok di Desa Jerukleueut Kecamatan Sindangwangi Kabupaten Majalengka. BERNAS: Jurnal Pengabdian Kepada Masyarakat, 1(3), 159-164. https://doi.org/10.31949/jb.v1i3.313

Ma'ruf, I. (2016). Budidaya lele sistem bioflok solusi ketahanan pangan masyarakat perkotaan. Jurnal Societa, $V(2), 82-86$,

Nugroho, E. (2019). Prospek teknologi budidaya ikan sistem bioflok sebagai alternatif model perikanan perkotaan di DKI Jakarta. Jurnal Riset Jakarta, 13(1), 1-6. https://doi.org/10.37439/jurnaldrd.v13i1.8

Ombong, F., \& Salindeho, I. R. N. (2016). Aplikasi teknologi bioflok (BFT) pada kultur ikan nila, Orechromis Niloticus). E-Journal Budidaya Perairan, 4(2), 16-25. https://doi.org/10.35800/bdp.4.2.2016.13018

Pebrianto. (2018). KKP: Konsumsi ikan ditargetkan 50, 8 kg per kapita pada tahun 2018. Tempo On line. Diakses pada tanggal 1 Februari 2019.

Prameswari, G. N. (2018). Promosi gizi terhadap sikap gemar makan ikan pada anak usia sekolah. Journal of Health Education, 3(1), 1-6.

Pramono, T. B., Marnani, S., \& Sukanto, S. (2018). Transfer teknologi bioflok pada budidaya ikan lele: Upaya peningkatan produktivitas usaha yang ramah lingkungan. Agromix, 9(2), 83-88.

https://doi.org/10.35891/agx.v9i2.1311 


\section{Budidaya Ikan Lele dengan Sistem Bioflok untuk Kawasan Permukiman}

Candra Dwiratna Wulandari, Sudiro, Titik Poerwati

Rizal, A., Yustiati, A., Suryana, A. A. H., \& Putro, R. D. (2018). Analisis komparasi keragaan usaha budidaya Ikan Lele Mutiara (Clarias Gariepinus) dengan dan tanpa sistem bioflok. Jurnal Perikanan Unram, 8(1), 65-70. https://doi.org/10.29303/jp.v8i1.73

Salamah, S., \& Zulpikar, Z. (2020). Pemberian probiotik pada pakan komersil dengan protein yang berbeda terhadap kinerja ikan lele (Clarias sp.) menggunakan sistem bioflok. Acta Aquatica: Aquatic Sciences Journal, 7(1), 21. https://doi.org/10.29103/aa.v7i1.2388

Sumardani, N. L. G., Suranjaya, I. G., Seminari, N. K., \& Radiawan, I. M. (2018). Kaji banding budidaya ikan lele dengan teknologi bioflok di Desa Ketewel Kecamatan Sukawati Kabupaten Gianyar. Buletin Udayana Mengabdi, 17(3), 61-66. https://doi.org/10.24843/bum.2018.v17.i03.p12

Sumitro, Afandi, A., Hidayat, K. W., \& Pratiwi, R. (2020). Evaluasi beberapa desain pipa mikropori sebagai sistem aerasi dalam budidaya Ikan Lele (Clarias Gariepinus) intensif berbasis teknologi bioflok. Journal of Aquaculture and Fish Health, 9(2), 114-121. https://doi.org/10.20473/jafh.v9i2.16692

Suryaningrum, F. M. (2014). Aplikasi teknologi bioflok pada pemeliharaan benih Ikan Nila (Oreochromisniloticus). Jurnal Manajemen Perikanan dan Kelautan, 1(1).

Setiawan, A., Ariqoh, R., Tivani, P., Pipih, L., \& Pudjiastuti, I. (2016). Bioflokulasi sistem teknologi budidaya lele tebar padat tinggi dengan kapasitas $1 \mathrm{~m} 3 / 750$ ekor dengan flock forming bacteria. Inovasi Teknik Kimia, 1(1), 45-49.

Zulfahmi, I., Syahimi, M., \& Muliari. (2018). Pengaruh penambahan bioflok dengan dosis berbeda terhadap pertumbuhan benih udang windu (Penaeus monodon FABRICIUS 1798). Al-Kauniyah: Jurnal Biologi, 11(1), 1-8 https://doi.org/10.15408/kauniyah.v11i1.4862 